\title{
ABCC5 wt Allele
}

National Cancer Institute

\section{Source}

National Cancer Institute. ABCC5 wt Allele. NCI Thesaurus. Code C103950.

Human ABCC5 wild-type allele is located in the vicinity of $3 q 27$ and is approximately $98 \mathrm{~kb}$ in length. This allele, which encodes multidrug resistance-associated protein 5, is involved in the transport of cyclic nucleotides. 